\title{
Assessing Indonesia's Leadership in the Advancement of ASEAN Political- Security Community under President Joko Widodo
}

\author{
Gibran Mahesa Drajat \\ Department of International Relations \\ President University \\ Indonesia \\ gmdrajat@gmail.com
}

\begin{abstract}
Abstrak
Makalah ini bertujuan untuk menelusuri kepemimpinan Indonesia dalam ASEAN seiring dengan berlangsungnya pembangunan komunitas kawasan politik dan keamanan ASEAN (ASEAN Political-Security Community atau APSC). Indonesia, sebagai negara terbesar di Asia Tenggara baik dari sisi geografi maupun ekonomi, diakui peran kepemimpinannya secara de facto dalam proses integrasi kawasan ASEAN. Integrasi yang disertai oleh kepemimpinan Indonesia tersebut menonjol terutama dalam bidang kerjasama multilateral, manajemen konflik, dan promosi demokrasi serta hak asasi manusia. Sejak Joko Widodo (Jokowi) dilantik menjadi Presiden Republik Indonesia pada Oktober 2014, Indonesia telah mengubah arah kebijakan luar negerinya terhadap ASEAN dengan membuka peluang bagi pendekatan lain yang dapat memajukan kepentingan nasionalnya. Dikarenakan adanya perubahan fokus kebijakan luar negeri Indonesia terhadap ASEAN, menjadi penting untuk mengevaluasi apabila pengembangan APSC akan terus berlangsung di bawah praktik diplomatik ASEAN (ASEAN Way) yang menitikberatkan musyawarah dan quiet diplomacy sebagai metode pengambilan keputusan.
\end{abstract}

Untuk membahas kepemimpinan Indonesia dalam pengembangan APSC di bawah kepresidenan Jokowi, makalah ini akan mengulas inisiatif-inisiatif yang diambil Indonesia untuk ASEAN dan bagaimana mereka berkontribusi terhadap regionalisme di Asia Tenggara. Tiga area kepemimpinan Indonesia dalam pengembangan APSC akan menjadi fokus dalam pengulasan insiatif-inisiatif yang dimaksud: pemeliharaan sentralitas ASEAN (ASEAN Centrality), manajemen sengketa Laut China Selatan, dan promosi demokrasi serta hak asasi manusia. Pada kesimpulannya, ASEAN berfungsi tidak hanya ketika anggota negaranya menemukan titik temu dalam isu regional yang juga mengakomodir politik dalam negerinya. Kehadiran kepemimpinan informal dan sukarela dari anggota negara ASEAN yang "senior dan berpengalaman" diperlukan untuk menjaga relevansi strategis ASEAN di Asia-Pasifik. Oleh karena itu, legitimasi Indonesia sebagai pemimpin informal yang diakui oleh ASEAN memiliki peran yang sangat penting untuk mendukung keutuhan dan sentralitas ASEAN kepada anggota negara lainnya.

Kata Kunci: Komunitas Politik dan Keamanan ASEAN, Kebijakan Luar Negeri Indonesia, Kepemimpinan Kawasan

\section{Abstract}

This paper aims to examine Indonesia's leadership in ASEAN as the regional organization advances its community building in areas of political-security. Indonesia, the largest state in Southeast Asia both from geographic and economic size, is known for its de facto leadership within the regional integration process of ASEAN. Such integration is mostly prominent in areas of multilateral engagement, conflict management, and democracy as well as human 
rights promotion. With President Joko Widodo at the helm of Indonesia's presidency since October 2014, Indonesia has reoriented its foreign policy cornerstone on ASEAN into other channels that best serve its national interest. As Indonesia repositions its focus from ASEAN, there is a need to evaluate whether the trajectory of ASEAN Political-Security Community will continue to thrive under the consensual decision-making process among its ten member states known as ASEAN way.

To evaluate Indonesia's leadership in the advancement of ASEAN Political-Security Community under President Joko Widodo, the paper will review Indonesia's initiatives to ASEAN and how they contribute towards Southeast Asia's regionalism. Subsequently, three areas of Indonesia's leadership in ASEAN Political-Security Community building will be examined: the maintenance of ASEAN Centrality, South China Sea dispute management, and promotion of democracy and human rights. The paper concludes that ASEAN way works not only when ASEAN member states find a common ground on regional issues that affect their respective domestic politics. A presence of informal and voluntary leadership where "matured" member states bring about initiative and persuasion is needed to maintain ASEAN's strategic relevance in Asia-Pacific. For this reason, Indonesia's legitimacy as an informal leader in ASEAN plays an important role to ensure that the organization remain united and central to its member states.

Keywords: ASEAN Political-Security Community, Indonesian Foreign Policy, Regional Leadership

\section{Introduction}

The study of leadership is vital to ASEAN as much as its study of diplomatic practice. Because ASEAN is an intergovernmental organization where its diplomacy places primacy on sovereignty, non-interference, and decision-making process through consensus, it requires strong initiatives and voluntary actions by its member states to bring its regional agenda forward. Additionally, the political system, ideology, and foreign policy priorities of ASEAN member states are different from one another. The presence of informal leadership is thus needed to ensure that progress is taking place at ASEAN multilateral forum.

This is where the role of Indonesia becomes pertinent. As the largest state in Southeast Asia in terms of geographical and economic size, Indonesia has been considered as a legitimate leader of ASEAN through its various proposals on security and defense areas. As Joko Widodo, also widely known as Jokowi, became the seventh President of Indonesia in October 2014, speculations began to arise that Indonesia would turn its back on ASEAN. While President Jokowi may have reoriented his foreign policy focus to domestic politics and placing regional efforts secondary to Indonesia's national sovereignty, there is a degree of continuity from Indonesia's stance on Political-Security community agenda within the ASEAN context.

In view of the above, it becomes important to examine how Indonesia's longtime efforts to advance its security and defense agenda in ASEAN has changed and continued under President Jokowi. To conduct this study, three areas of ASEAN Political-Security agenda are chosen. These include ASEAN Centrality, South China Sea dispute, and Democracy and 
Human Rights Promotion. The selection is based on considerations that Indonesia has actively engaged on advancing the agenda and facilitating dialogue between relevant parties on these three areas. What ultimately changed in the course of Jokowi's presidency is a more pragmatic approach in balancing Indonesia's national interest and its role as a regional player in East Asia.

In order to effectively assess how Indonesia's leadership in ASEAN Political-Security Community is heading under President Jokowi, this paper revisits the role and initiatives that Indonesia has taken in the three selected aforementioned areas. It subsequently evaluates the foreign policy choices that President Jokowi is taking with respect to ASEAN PoliticalSecurity agenda. This is done not only through synthesis of academic literature and conference presentations related to the subject, but also official statements from the President as well as relevant ministries officials and government insiders. Even as this paper takes into account the multifaceted foreign policy formulation from various state actors within President Jokowi's administration, the agential factor of a state leader arguably determines the extent to which a state conduct its foreign relations. This study also comes not without limitation. Since Jokowi's presidency is still ongoing, the foreign policy direction that Indonesia is undertaking with regards to ASEAN Political-Security Community can still be subject to change.

This paper is divided into four subsequent sections. The next section evaluates the presence of leadership in ASEAN and how Indonesia fits into its conceptualization. An assessment is also made on how ASEAN, as an institution, lacks formal leadership and why it remains to rely on the goodwill of its member states to move regional agenda forward. Afterwards the next three sections will explore Indonesia's initiatives on the selected areas of ASEAN Political-Security community and how President Jokowi is moving the agenda forward. Finally, the paper concludes with the discussion of findings and how Indonesia remains important to the regional evolution of ASEAN.

\section{Regional Leadership within ASEAN}

Before assessing the leadership role that Indonesia plays in the advancement of ASEAN Political-Security Community, there is a need to revisit the conceptualization of leadership in the context of Southeast Asia. In ASEAN itself, each member states are given the opportunity to serve as an ASEAN chair by alphabetical order on an annual basis (ASEAN Charter, 2007, p. 27). The chairmanship role that ASEAN member states play amplifies the presence of formal leadership in the organization. There is however another facet of leadership wherein various initiatives are taken by member states without prior obligation from the ASEAN institutional framework. This is known as the informal leadership that exists beyond the chairmanship clause in ASEAN Charter (Rattanaseeve, 2014, p. 118). It is this type of leadership that shapes the regional agenda more strongly than the formal approach.

According to Rattanaseeve (2014), the informal leadership that is present in ASEAN can be divided into three categories. The first category is sectorial leadership, which is broadly defined by Emmers (2014) and Rattanaseeve (2014) as responsive approach to regional 
events that is exhibited through areas or sectors that the particular state is specializing in a given time. In much of the literature on regional leadership in ASEAN, Indonesia is said to have exercised this form of leadership. Emmers (2014) argues that Indonesia's focus on sectorial leadership has been prominent in areas of political and security spheres while leaving "the economic sector to neighboring states (p. 550)." This is similarly emphasized by Heiduk (2016) who points out that Indonesia's main interests in foreign policy when it comes to ASEAN and "regional integration... have always been in the area of security and defense (para. 5)." Rattanaseevee (2014) also commented that Indonesia is generally considered as the forefront actor of security and political matters in ASEAN. Indonesia's consistency on prioritizing its foreign policy agenda to political and security field vis-à-vis ASEAN cooperation makes this study even more important to Southeast Asia's regionalism. Under Jokowi's presidency, there is a need to assess whether this continuation of sectorial leadership remains relevant to the discourse of International Relations in Southeast Asia.

The second type of informal leadership that is presented by Rattanasevee (2016) is cooperative leadership or also known as coalition leadership. This is defined as “...leadership formed among a group of countries that share a common vision and wish to play a strategic role in the region (Rattanasevee, 2016, p. 119)." Although ASEAN has been praised for curbing the competition of various national interests from its member states and its success in maintaining intra-regional peace and stability (Weatherbee, 2009, p. 127; Phan, 2013, p. 48), the diversity of political systems and ideology hinders much of the ASEAN Political-Security Community (APSC) agenda from moving forward. This includes the diverging views on ASEAN Centrality, South China Sea, and Democracy and Human Rights promotion that will be further elaborated in the subsequent sections. It is important to note that while ASEAN is widely credited for promoting peace and stability in the Southeast Asia region, its member states have yet to share common vision that would otherwise strengthen the institutional capacity of ASEAN. For this reason, the leadership of ASEAN remains to be voluntary and highly dependent on the initiatives taken by its influential member states to set up the ASEAN regional agenda.

The third type of leadership that exists in ASEAN is periodical leadership which assumed that "leadership is attached to individuality or personal ability (Rattanasevee, 2014, p. 119)." By taking into account the scholarly view on Indonesia's sectorial leadership in ASEAN and Jokowi's individual and personal preference on foreign policy agenda, the agential role of the President arguably plays a role in determining the direction of Indonesia's partnership towards ASEAN. This becomes evident when Jokowi and his predecessor's approach to foreign relations are determined not only by the sector that the state is specializing in at the time, but also the experience and perception of the national leader itself towards its external environment. As a result, there is a linkage between the decision taken by the state actors to provide leadership on certain foreign policy areas that they are most comfortable with and the discretion made by the head of state and/or government as to how far such leadership should be extended. This will be fully demonstrated after examining the initiatives taken by Indonesia in three selected areas of ASEAN Political-Security Community agenda and 
whether President Jokowi continues to emphasize Indonesia's involvement in those three areas.

Aside from the evaluation of ASEAN chairmanship and informal leadership that exist within the regional organization, the lack of formal leadership in ASEAN is also attributed to its diplomatic norms and culture. The ASEAN approach to decision-making and norm-based organizational principles, known as ASEAN way, pays a considerable attention to consensusbuilding as well as adherence to sovereign equality, peaceful settlement of disputes and nonuse of force, policy of non-interference in states' domestic affairs, and quiet diplomacy (Haacke, 2005, p. 7; Kawai et al., 2016, p. 17). Because of this, ASEAN as a collective entity is often considered reactive to the evolving regional issues rather than taking a proactive lead in shaping and leading an autonomous agenda (Kawai et al., 2016, p. 18). This view is also expanded by Rattanasevee (2014, p. 114) who made it clear that the "leaderless" nature of ASEAN can be detrimental to regional integration in Southeast Asia. Indeed, ASEAN embodies the neorealist and neoliberal contention that international organizations serve as a platform for states to further their interests and more specifically accommodate the diverse national situations of ASEAN member states (Barnett and Finnemore, 1999, pp. 703-704; Kawai et al., 2016, p. 17). Given the existing norms and principles that constrain structural exercise of formal leadership in ASEAN, the position and foreign policy choices that Indonesia is making towards its adjacent region cannot be easily overlooked.

\section{Maintenance of ASEAN Centrality}

ASEAN Centrality is a vital concept to the studies of the regional organization and International Relations in Southeast Asia. Its importance began to evolve after the Cold War when ASEAN plays a more active security role within East Asia (Koga, 2013). Indonesia's role in ensuring the centrality of ASEAN however can be traced back during early years of ASEAN's establishment. In order to evaluate Indonesia's stance on ASEAN Centrality and President Jokowi's position in that regards, there is a need to revisit how ASEAN Centrality itself was conceptualized.

The conceptualization of ASEAN Centrality is best defined by Caballero-Anthony (2014) which is "about ensuring that regional processes and engagements are coursed through and defined by ASEAN-led mechanisms (pp. 570-571)." This view is also shared by Chalermpalanupap (2014) who emphasizes the concept as ASEAN's focus "on securing the primary driving force role in all the dialogue and cooperation processes (p. 68)." To measure the extent to which ASEAN can lead the regional and cooperation processes, CaballeroAnthony (2014, p. 571) operationalizes two key indicators of ASEAN-led mechanisms and its relationship with external partners. The first is the ability of ASEAN to decide on new membership into the regional organization and dialogue partnership. With this respect, ASEAN has been successful both in procedural and substantive terms to decide the organizational membership by its own. Procedurally, ASEAN made it possible for Southeast Asian states to accede to Treaty of Amity and Cooperation (TAC) (1976, art 18). Article 6 of ASEAN Charter (2008) outlines the mechanisms to which new members can join ASEAN through consensus from all of its member states. In addition, the first (1987) and second 
protocol (1998) amending the TAC enables other states outside Southeast Asia to enter the treaty in order to establish a dialogue and strategic partnership with ASEAN. In substance, the provisions to TAC have been effective in attracting external powers to acknowledge ASEAN as an institutional player in the Asia-Pacific. As of 2014, most major and regional powers including China, Japan, India, Russia, and the United States have all acceded to TAC which underscored the success of ASEAN in deciding not only its internal membership configuration but also external relations and partnership (Caballero-Anthony, 2014, p. 570).

The second element is how well ASEAN can set its own agenda for the regional cooperation to move forward (Caballero-Anthony, 2014, p. 572). In other words, ASEAN seeks to prevent major powers from marginalizing its influence in the region and push them into the sidelines (Tamotsu, 2015, p. 27). Unlike ASEAN's success in deciding its membership, hurdles remain when ASEAN is tasked with setting up its own regional agenda. This is mostly due to the organization's lack of unity and cohesion from its member states. As will be discussed in the following two subsections, Indonesia's effort to promote ASEAN Centrality is constrained by the divergence of ASEAN member states' foreign policy.

In addition to the two key elements above, ASEAN Centrality is measured by the intraASEAN relations itself (Caballero-Anthony, 2014, p. 573). Caballero-Anthony argues that the closeness and degree of centrality among the ASEAN member states is a determining factor to how ASEAN remain cohesive and thus relevant to its member states' foreign relations. This view is also shared by Ambassador Jose Antonio Morato Tavares ${ }^{1}$ (2018) of Indonesia who stated that the essence of ASEAN Centrality is "how ASEAN member states can manage, can balance their national interest in relations with dialogue partners that does [sic] not jeopardize regional interest." The underlying process of ASEAN Centrality here is that in order for ASEAN to be at the center of decision-making process in Asia-Pacific region, there is a need for the member states to be united and cohesive in carrying the ASEAN agenda forward.

\subsection{Indonesia's Role and Initiatives on ASEAN Centrality}

Indonesia, as stated in much of the literature on ASEAN Centrality, has been in the forefront of autonomous and ASEAN-led regional order. Four years after the establishment of ASEAN, the first political regional initiative within the organization was established to ensure that ASEAN is free from external interference (Weatherbee, 2009, pp. 74-75). The resulting declaration from this initiative is known as Zone of Peace, Freedom, and Neutrality (ZOPFAN). It should be noted that ZOPFAN has no enforcement mechanism thereby rendering ASEAN member states with voluntary choice on whether to abide by the declaration (Weatherbee, 2009, p. 75). Indonesia, whose foreign policy is driven by principle of "independent and active" politics ${ }^{2}$, has embraced the principle of external non-interference

\footnotetext{
${ }^{1}$ Ambassador of Indonesia to New Zealand from 2013 to 2016. Currently serving as Director General for ASEAN Cooperation at the Ministry of Foreign Affairs of Indonesia.

2 Politik Bebas Aktif or "Independent and Active" Politics is Indonesian foreign policy principle crafted by the country's first Vice President Mohammad Hatta in 1948. It is grounded on the premise that Indonesia's foreign 
that is enshrined in ZOPFAN (Moniaga, 2015, pp. 2, 18; Gindarsah and Priamarizki, 2015, p. 137). In addition, Indonesia accentuates the role that ASEAN should play in "shaping strategic initiatives for the construction of the region's security architecture (Gindarsah and Priamarizki, 2015, p. 137).”

From the point of view of ASEAN Centrality with external partners, Indonesia has been a strong advocate of an ASEAN-led regional order where the organization is not bound by external interference. This stance has been persistent throughout Indonesia's foreign relations but garnered few support from ASEAN member states that considered involvement of major powers to be in their respective national interest. Examples given by Emmers (2014, p. 548) include the Philippines and Thailand who preferred to maintain their security link with the United States as well as Singapore who perceived American presence in the Asia-Pacific as vital to its security. Similar problem is also found on issues of ASEAN Centrality in the South China Sea dispute which will be discussed in the subsequent section. This case demonstrates that the common vision of ASEAN member states' in maintaining the unity and centrality of the organization is largely absent due to divergence of foreign policy choices. Unless the concept of ASEAN Centrality is shared by ASEAN member states, it is unlikely that ASEAN can effectively lead a regional agenda that transcends dialogue and meeting facilitation.

\subsection{President Jokowi's Policy on ASEAN Centrality}

When Jokowi became Indonesia's seventh President in October 2014, there have been concerns as to whether the then newly elected President would turn his back on ASEAN and thereby undermining ASEAN Centrality. Parameswaran (2014) quoted Rizal Sukma, who was then the foreign policy adviser to the President, in saying:

"We used to say ASEAN is the cornerstone of our foreign policy. Now we change it to a cornerstone of our foreign policy (para. 3)".

Furthermore, Parameswaran (2014) made the argument that Indonesian foreign policy would become "more domestic-oriented and bilateral under Jokowi (para. 8)." While Poole (2015, para. 11) also made similar claim that Jokowi's administration has shifted from liberal internationalism, Harding and Merchant (2016, para. 3) went further by claiming that Indonesia has taken an inward-turn and retreated from its leadership role in ASEAN under Jokowi's Presidency.

The worries that Indonesia would move away from ASEAN under Jokowi's presidency however has been exaggerated (Heiduk, 2016). In spite of the fear that Indonesia would look to avenues other than ASEAN in advancing its national interest, various statements that have been released by President Jokowi and his administration demonstrates Indonesia's continuity in upholding ASEAN Centrality. During the ASEAN Summit plenary meeting in Vientiane 
on September 2016, President Jokowi was quoted by Salim (2016) of the Jakarta Post for saying:

We cannot turn a blind eye to the instability that is emerging in our region. We cannot let powerful countries dictate us and determine the fate of regional security and stability.....without ASEAN unity and centrality, I am certain that ASEAN's ability to maintain regional peace and stability will erode (para. 5 and 7).

Seven months later in ASEAN Summit in Manila, President Jokowi reiterated his stance on promoting ASEAN Centrality. He was also quoted by Halim (2017) of the Jakarta Post for saying:

Do not let ASEAN become a proxy of the rivalry of big powers....ASEAN must always be a hub for regional diplomacy (para. 4).

These statements illustrate that there is continuity on the part of Jokowi's administration to advance Indonesia's stance in maintaining ASEAN Centrality. The annual press statement by the Minister of Foreign Affairs in 2016 also accentuates that ASEAN is the cornerstone of Indonesia's foreign policy (Ministry of Foreign Affairs of Indonesia, 2016, p. 11). This is reasserted in the same press statement two years later where Foreign Minister Retno Marsudi underlines ASEAN unity and centrality's alignment with the national interest of Indonesia (Ministry of Foreign Affairs of Indonesia, 2018, p. 5). The challenge for President Jokowi's foreign policy team is how to ensure that Indonesia's promotion of ASEAN centrality can be seen attractive to other member states. This can be simultaneously viewed as Indonesia's prospect of extending its soft power capability to ASEAN member states (Nye, 2004, p. 6). Although the opportunity for President Jokowi to use ASEAN Centrality as a selling point is within reach, Indonesia's preference for an autonomous regional order has yet to convince other ASEAN member states to reconcile their domestic politics with an ASEAN-centered foreign policy (Emmers, 2014, p. 559).

\section{South China Sea Dispute Management}

The South China Sea dispute has been a protracted source of tension among claimants from four ASEAN member states, China, and Taiwan (Lowly Institute, 2013). Indonesia's effort to mitigate the potential conflict in South China Sea can be traced back since 1990 when it has already put forward several formulations with regards to the Code of Conduct $(\mathrm{CoC})$ in South China Sea (Roberts and Widyaningsih, 2015, p. 269). What is noteworthy about Indonesia's diplomacy in South China Sea is the change of position from taking a lead in regional security to defending its maritime interest in the Natuna Sea under Jokowi's Presidency. Indonesia has conflicting maritime areas with China to the north of Natuna Islands where Indonesia's Exclusive Economic Zone (EEZ) overlaps with China's nine-dash line (Connelly, 2015, p. 19).

\subsection{Indonesia's Role on South China Sea Dispute}


Indonesia has long regarded itself as a non-claimant in the South China Sea dispute, enabling it to play a role of "honest broker" in talks and negotiations over the issue from 1990 to 2014 (Connelly, 2016, p. 4). The labeling of non-claimant to the dispute however should be understood in a sense that China and Indonesia do not have sovereignty dispute over any land features but still have competing maritime claims (Connelly, 2016, p. 3). Because the overlapping maritime claims were generally kept quiet by the Indonesian government for the sake of facilitating dialogue among the claimant states, Indonesia's long standing policy has been to lead the dispute management mechanisms rather than asserting its self-interest in Natuna Islands (Connelly, 2015, pp. 19-20; Connelly 2016, p. 1; Roberts and Widyaningsih, 2015, p. 269). A prominent display of Indonesia's leadership in South China Sea dispute was when the then foreign minister Marty Natalegawa undertook a shuttle diplomacy to Cambodia, Vietnam, and the Philippines after the ASEAN Ministerial Meeting in July 2012 failed to issue a joint communiqué on South China Sea dispute (Roberts and Widyaningsih, 2015, p. 268; Emmers, 2014, pp. 552-553). “ASEAN Six-Point Principles on South China Sea" were subsequently agreed upon and accepted by all ASEAN member states through their respective foreign ministers (Roberts and Widyaningsih, 2015; Emmers, 2014).

Under President Jokowi, there has been a shift on Indonesia's role and approach in South China Sea dispute from taking a leadership role in regional dispute to assertion of sovereignty off the coast of Natuna Islands. Regardless of this policy shift, and similar to his position in ASEAN Centrality, President Jokowi remains consistent in voicing the needs for ASEAN to come together and cooperate with China on the South China Sea dispute.

\subsection{President Jokowi's Policy on South China Sea Dispute}

In order to examine the change in Indonesia's approach towards South China Sea dispute under President Jokowi, there is a need to account for the three separate encounters between Chinese fishing boats and Indonesian marine vessels in 2016. This is subsequently followed by decision by Indonesian government to rename northern part of its Natuna Islands a year after to North Natuna Sea, much to Chinese displeasure (Parameswaran, 2017).

The first encounter occurred on 19 March 2016 where a Chinese fishing boat captured by Indonesia's Ministry of Marine Affairs and Fisheries vessel were forced to be released by the Chinese Coast Guard as the former approaches Indonesia's territorial waters (Connelly, 2016, p. 5). This is closely associated with President Jokowi's crackdown on illegal fishing by publicly sinking any seized foreign fishermen's boat as a deterrent effect to other illegal fishers (Parameswaran, “The Trouble with Indonesia's Foreign Policy Priorities Under Jokowi," 2015; Connelly, 2016). Two days after the incident, the Minister of Marine Affairs of Fisheries, Susi Pudjiastuti made a statement that the Chinese decision to interfere with the Indonesian arrest is based on the fear that another Chinese fishing vessel may be sunk under President Jokowi's illegal fishing measures (Ariyanti, 2016). It should be noted that Indonesia had sunk one Chinese vessel caught fishing illegally on Indonesian waters near Natuna Islands on May 20, 2015 (Parameswaran, "Indonesia Sinks First Vessel From China Under Jokowi,” 2015). This illustrates the clash between President Jokowi's domestic policy 
on maritime affairs with Indonesia's leadership role to mitigate regional dispute in South China Sea.

The second incident occurred two months later on 27 May when Indonesian navy arrested eight Chinese fishermen and confiscating their boat east of Indonesia's EEZ Boundary (Connelly, 2016, pp. 5-6). Unlike the encounter on 19 March, the Chinese Coast Guard did not interfere with the arrest but China's Foreign Ministry issued a protest afterwards (Connelly, 2016, p. 6). The third incident took place less than a month later on 17 June where Indonesia's navy warship KRI Imam Bonjol clashed with Chinese fishing vessels and detaining seven people on board (Kwok, 2016).

The 17 June incident is considered as the peak of Indonesia's assertiveness in South China Sea dispute. Six days after the incident, President Jokowi visited the Natuna Islands and held a limited cabinet meeting on board KRI Imam Bonjol as a strong signal to China over Indonesia's resolve to defend its maritime rights around the Natuna Islands (Kwok, 2016). Beijing responded two days after the incident where its Foreign Ministry openly declared that for the first time that the Natuna waters is an area "where China and Indonesia have overlapping claims for maritime rights and interests (Ministry of Foreign Affairs of the People's Republic of China, 2016)." Indonesia's changing role in South China Sea dispute from honest broker to guaranteeing the territorial integrity of Indonesia should not however come as a surprise as it is in accordance with Jokowi's vision and mission statement on foreign policy when he was still a presidential candidate (Connelly, 2015, p. 8). What is interesting is that, in spite of this change, there is also continuity in President Jokowi's stance that ASEAN should remain united in managing the South China Sea dispute.

In spite of Jakarta's reaction to its maritime clashes with Beijing, Indonesia's leadership to South China Sea dispute under President Jokowi is not a simple reversal from active involvement on regional issues to domestic-oriented foreign policy. President Jokowi was quoted speaking to the South China Morning Post after the ASEAN Summit in Manila in April 2017 that he has proposed disputants of South China Sea to engage in concrete cooperation before proceeding to negotiation with China (Wong, 2017). In other words, Indonesia emphasizes a need to settle the internal differences between ASEAN member states on the South China Sea dispute and take a common stand in future communication with China (Wong, 2017). Similar to the issue of ASEAN Centrality, not every ASEAN member states share a common position on South China Sea dispute. As stated by Poole (2017), there are those in ASEAN who are claimants in the dispute, e.g. Malaysia, Brunei, the Philippines, and Vietnam, while others, e.g. Cambodia and Laos, are close to China and support the Chinese preference to keep the dispute away from multilateral engagements. The reason why 2012 ASEAN Ministerial Summit in Phnom Penh failed to produce joint communiqué was also attributed to the fact that Cambodia was acting as China's close economic partner and followed Beijing's directive of not raising South China Sea dispute to any multilateral discussion (Emmers, 2014, p. 553). 
The case of South China Sea dispute and ASEAN Centrality demonstrates that Indonesia has taken a pragmatic approach in strengthening its own maritime capacity while voicing its continuous foreign policy stance of open regionalism and encouraging active participation of ASEAN member states in various defense and security issues. There is however fewer attention given in area of democracy and human rights promotion, an agenda that Indonesia has strongly proposed throughout the formation of ASEAN Political-Security Community.

\section{Democracy and Human Rights Promotion}

Democracy and Human Rights are two concepts that were initially placed into sidelines by most ASEAN member states prior to the initiation of APSC building in 2003. Indeed, the idea of ASEAN Security Community (ASC), which was later renamed to ASEAN PoliticalSecurity Community, came from Indonesia during the Declaration of Bali Concord II at the ASEAN Summit in October 2003 (Acharya, 2014, p. 226; Yuzawa, 2013, p. 242). When Indonesia was asked to implement the ASC, its first draft of plan of action includes the promotion of democracy and human rights (Acharya, 2014, pp. 229-230; Emmers, 2014, p. 556). Similar to Indonesia's advocacy of ASEAN Centrality through ZOPFAN in the early conception of ASEAN, Indonesia's proposal to include provisions on democracy and human rights to ASC Plan of Action was met with opposition from less democratic ASEAN member states (Yuzawa, 2013, pp. 242-243). In addition, Indonesia's promotion of democracy and human rights at the initiation of ASC was seen as an attempt to reassert its leadership from the aftermath of 1997 Asian financial crisis (Acharya, 2014, p. 231; Emmers, 2014, p. 556). Even though Indonesia had to eventually tone down the references to democracy and human rights on ASC Plan of Action, Yuzawa (2013) argues that the final draft of the document "retains important elements of the democracy and human rights agenda proposed by Indonesia (p. 243)." An example of this is when in July 2007, ASEAN member states agreed to create 'human rights body' which in two years evolved to what is now known as the ASEAN Intergovernmental Commission on Human Rights (AICHR) (Roberts and Widyaningsih, 2015, p. 271).

Indonesia's leadership in including democracy and human rights promotion to APSC agenda illustrates the need for ASEAN member states not to be seen as too powerful when it comes to extending its leadership to the region. As in the case of ASEAN Centrality and South China Sea dispute, the ASEAN member states do not share the same experience and political values with regards to democracy and human rights (Yuzawa, 2013, p. 241). There is a need therefore for President Jokowi to continue Indonesia's policy on advancing democracy in the region without having to pressure its counterparts to reform (Moniaga, 2015, p. 18). At the same time, questions began to emerge as to whether democracy and human rights remain to be a part of Indonesia's foreign policy agenda under Jokowi's presidency (Tavares et al., 2018). On one hand, Foreign Minister Retno Marsudi emphasizes Indonesia's role in Universal Periodic Review of United Nations Human Rights Council (UNHCR) and that democracy and human rights will continue to be an asset for Indonesia's diplomatic relations (Ministry of Foreign Affairs of Indonesia, 2018, p. 7). On the other hand, Ibrahim Almuttaqi, who is the head of ASEAN Studies Program at Habibie Center in Jakarta, cited the failure of the President to attend the $10^{\text {th }}$ Bali Democracy Forum last December 2017 and question 
whether Indonesia's foreign policy is still committed towards democracy and human rights promotion (Tavares et al., 2018). The challenge for President Jokowi is whether to use democracy and human rights as a form of soft power and national image like his predecessor or remain pragmatic in its approach like ASEAN Centrality and South China Sea dispute.

Indonesia's advocacy of democratic inducing foreign policy is particularly enshrined during Susilo Bambang Yudhoyono's presidency, predecessor of President Jokowi who considered democracy not only as a political system that Indonesia embraced but also a national brand (Moniaga, 2015, p. 20). Yudhoyono's focus on his foreign policy is among other the heavy investment of Indonesia's image on democratic achievements and its ensuing acknowledgement by the international community that Indonesia is a role model where Islam, democracy, and modernity can coexist (Moniaga, 2015, pp. 1, 20-21). An example of this was the establishment of Bali Democracy Forum in 2008 where willing participants meet annually in Bali $^{3}$ to share their experience and best practices with regards to peace and democracy (Weatherbee, 2013, p. 30). President Jokowi would need to decide whether Indonesia will continue to invest in its soft power as the third largest democracy. Similar to Indonesia's call to persuade ASEAN member states to remain united in driving the regional agenda, Jokowi's administration could also make similar investment with that regards. Alternatively, Jokowi could take a more pragmatic step in Indonesia's democracy and human rights promotion agenda. By placing emphasis on strengthening the democratic institutions and processes from within Indonesia's domestic politics first, the President can henceforth share Indonesia's experience on how the state continues to democratize under his administration. Due to past efforts by the Indonesian government to advance democracy and human rights promotion within the ASEAN multilateral forum, it is in the interest of Indonesia to continue such advancement in its foreign policy.

\section{Conclusion: How does Jokowi approach ASEAN Political-Security Community agenda in his Presidency?}

Indonesia's leadership in ASEAN remains to be driven by areas or sectors where the state has better position to lead at a given time. With Indonesia's track record as a sectorial leader on areas of defense and security, President Jokowi continues to echo the continuous sets of policy that maintains ASEAN Centrality including any multilateral effort in Southeast Asia to mitigate the South China Sea dispute. At the same time, leadership based on individual and personality trait also plays a role in Indonesia's approach towards advancing ASEAN Political-Security Community agenda. As a pragmatic leader, Jokowi provides a mixture of Indonesia's foreign policy approach where Indonesia defends its territorial integrity while at the same time encourages its Southeast Asian counterparts to remain united in the ASEAN forum.

In area of ASEAN Centrality, Indonesia has been advocating ASEAN to be the driver for regional security architecture and reject to be sidelined by great power competition in

\footnotetext{
${ }^{3}$ An exception of this is the 2017 Bali Democracy Forum where it was held in Serpong, Banten (Ministry of Foreign Affairs of Indonesia, 2017).
} 
Southeast Asia. This is in line with Indonesia's foreign policy principle of "independent and active" politics. Even though President Jokowi's adviser made a signal that Indonesia would look for other avenues to advance its national interest, this does not entail Indonesia's abandonment of ASEAN from its foreign policy agenda. On the contrary, President Jokowi's statements at two ASEAN Summits accentuate Indonesia's continuity to promote autonomous regional order and greater unity by ASEAN member states to strengthen ASEAN institutional capacity.

In area of South China Sea dispute, Indonesia and China had long maintained quiet diplomacy when it comes to overlapping maritime claims, thereby enabling the former to play a mitigating role in the dispute. As Jokowi became President, Indonesia had taken a more assertive role in maintaining its territorial integrity around the Natuna Islands. At the same time, Indonesia also encourages ASEAN member states to formulate a unified position on South China Sea dispute before bringing up the matters with China. This exemplifies Indonesia's growing pragmatism that seeks to balance its resolve to safeguard national sovereignty while encouraging active involvement from ASEAN member states to drive the dispute management process forward.

Much of the unknown still exists on whether Indonesia remains committed to promoting democracy and human rights. Drawing from strategic choice that President Jokowi has taken on areas of ASEAN Centrality and South China Sea dispute, Indonesia can opt to use democracy and human rights as a national brand and source of soft power as it had under Yudhoyono's presidency or it can balance its promotion with prior emphasis on domestic politics.

In the end, because not every ASEAN member states share the same visions, positions and values in all the three areas that have been examined, leadership in ASEAN is important not only at formal chairmanship but also informal level. As illustrated by the breakdown of 2012 ASEAN Ministerial Meeting, it is the initiative of Indonesia as "matured" ASEAN member state that breaks the deadlock through shuttle diplomacy instead of Cambodia who chaired ASEAN at the time. As long as the diplomatic culture of ASEAN is still centered on consensual decision-making process and non-interference and that different political interest and ideologies still exist among its member states, constant initiatives by ASEAN member states to carry out the regional agenda is still required at large. For this reason, to ensure that ASEAN remains united and relevant to regional security architecture is only the start. Until ASEAN eventually shares a common vision on regional issues that is considered accommodative to the national interest of its member states, ASEAN needs a benign leadership that helps the organization to drive the regional process forward.

\section{References}


Acharya, A. (2014) Constructing a Security Community in Southeast Asia: ASEAN and the Problem of Regional Order. $3^{\text {rd }}$ ed. Routledge.

Ariyanti, F. (2016) Ini Sebab RI Gagal Tangkap Kapal Pencuri Ikan Tiongkok di Natuna. Retrieved from http://bisnis.liputan6.com/read/2463798/ini-sebab-ri-gagal-tangkap-kapalpencuri-ikan-tiongkok-di-natuna

Association of Southeast Asian Nations. (2007) The ASEAN Charter. Jakarta: The ASEAN Secretariat.

(1987) Protocol Amending the Treaty of Amity and

Cooperation in Southeast Asia. Retrieved from
http://agreement.asean.org/media/download/20131231005052.pdf

(1976) The Treaty of Amity and Cooperation in Southeast Asia. Retrieved from http://asean.org/treaty-amity-cooperation-southeast-asiaindonesia-24-february-1976/

(1998) Second Protocol Amending the Treaty of Amity

and Cooperation in Southeast Asia. Retrieved from http://agreement.asean.org/media/download/20140117142023.pdf

Barnett, M.N., \& Finnemore, M. (1999). The Politics, Power, and Pathologies of International Organizations. International Organization, 53 (4): 699-732.

Caballero-Anthony, M. (2014) Understanding ASEAN's centrality: bases and prospects in an evolving regional architecture. The Pacific Review, 27 (4): 563-584.

Chalermpalanupap, T. (2014) ASEAN Managing External Political and Security Relations. Southeast Asian Affairs, 41: 53-75.

Connelly, A.L. (2014) Indonesian foreign policy under President Jokowi (Analysis). Sydney: Lowy Institute for International Policy.

Connelly, A.L. (2016) Indonesian in the South China Sea: Going it alone (Analysis). Sydney: Lowy Institute for International Policy.

Connelly, A.L. (2015) Sovereignty and the Sea: President Joko Widodo's Foreign Policy Challenges. Contemporary Southeast Asia, 37 (1): 1-28.

Embassy of the Republic of Indonesia Washington D.C. Indonesia's Foreign Policy/The Principles of the Foreign Policy. Retrieved from https://www.embassyofindonesia.org/index.php/foreign-policy/

Emmers, R. (2014) Indonesia's role in ASEAN: A case of incomplete and sectorial leadership. The Pacific Review, 27 (4), 543-562.

Gindarsah, I., \& Priamarizki, A. (2015) Politics, Security and Defense in Indonesia: The Pursuit of Strategic Autonomy. In C.B. Roberts, A.D. Habir \& L.C. Sebastian (Eds.), 
Assessing Indonesia's Leadership in the Advancement of ASEAN Political-Security Community under President Joko Widodo

Indonesia's Ascent: Power, Leadership, and Regional Order (pp. 130-154). London: Palgrave MacMillan.

Haacke, J. (2005) ASEAN's Diplomatic and Security Culture: Origins, Development and Prospects. Oxon: Routledge.

Halim, H. (2016) Don't let ASEAN become 'proxy' of rivalry between big powers: Jokowi. Retrieved from http://www.thejakartapost.com/seasia/2017/04/30/dont-let-asean-becomeproxy-of-rivalry-between-big-powers-jokowi.html

Harding, B., \& Merchant S. (2016) Indonesia's Inward Turn. Retrieved from https://thediplomat.com/2016/12/indonesias-inward-turn/

Heiduk, F. (2016) Finding Regionalism in Jokowi's Foreign Policy. Retrieved from https://thediplomat.com/2016/05/finding-regionalism-in-jokowis-foreign-policy/

Kawai, M., Thuzar, M., \& Hayton, B. (2016) ASEAN'S Regional Role and Relations with Japan: The Challenges of Deeper Integration (Research Paper). London: Chatham House.

Koga, K. (2013) ASEAN's Great Power Dilemma. Retrieved from http://belfercenter.hks.harvard.edu/publication/22784/aseans_great_power_dilemma.html?bre adcrumb $=\% 2$ Fexperts $\% 2$ F2644\%2Fkei_koga

Kwok, Y. (2016) Indonesian President Jokowi Visits the Natuna Islands to Send a Strong Signal to China. Retrieved from http://time.com/4379401/indonesia-china-jokowi-natunasovereignty-maritime-fishing-dispute/

Lowy Institute. (2013) South China Sea. Retrieved from https://www.lowyinstitute.org/issues/south-china-sea

Ministry of Foreign Affairs of Indonesia. (2017) $10^{\text {th }}$ Bali Democracy Forum: Building a Culture of Dialogue in One Decade. Retrieved from: https://www.kemlu.go.id/en/berita/berita-perwakilan/Pages/10th-Bali-Democracy-Forum-Building-a-Culture-of-Dialogue-in-One-Decade.aspx

(2016). Pernyataan Pers Tahunan Menteri Luar Negeri Republik Indonesia Retno L.P. Marsudi Tahun 2016. Retrieved from: https://www.kemlu.go.id/id/pidato/menlu/Pages/PPTM\%202016\%20Menlu\%20RI.pdf

(2018). Pernyataan Pers Tahunan Menteri Luar Negeri Republik Indonesia Y.M. Retno L.P. Marsudi Tahun 2018. Retrieved from: https://www.kemlu.go.id/id/pidato/menlu/Pages/PPTM2018\%20MENLU\%20RI\%20IN.pdf

Ministry of Foreign Affairs of the People's Republic of China. (2016). Foreign Ministry Spokesperson Hua Chunying's Remarks on Indonesian Navy Vessels Harassing and Shooting Chinese Fishing Boats and Fishermen. Retrieved from: http://www.fmprc.gov.cn/mfa_eng/xwfw_665399/s2510_665401/t1373402.shtml

Moniaga, R. J. (2015, January) Indonesia's Past, Present and Future Power, Image and Foreign Policy. Paper presented at the ISA Global South Caucus Conference, Singapore. 
Nye, J. (2004) Soft Power: The Means to Success in World Politics. $1^{\text {st }}$ ed. Public Affairs.

Parameswaran, P. (2015) Indonesia Sinks First Vessel From China Under Jokowi Retrieved from https://thediplomat.com/2015/05/indonesia-sinks-first-vessel-from-china-under-jokowi/

Parameswaran, P. (2014) Is Indonesia Turning Away From ASEAN Under Jokowi? Retrieved from https://thediplomat.com/2014/12/is-indonesia-turning-away-from-asean-under-jokowi/

Parameswaran, P. (2015) The Trouble With Indonesia's Foreign Policy Priorities Under Jokowi Retrieved from https://thediplomat.com/2015/01/the-trouble-with-indonesias-foreignpolicy-priorities-under-jokowi/

Parameswaran, P. (2017) Why Did Indonesia Just Rename Its Part of the South China Sea? Retrieved from https://thediplomat.com/2017/07/why-did-indonesia-just-rename-its-part-ofthe-south-china-sea/

Phan, H.D. (2013). Procedures for Peace: Building Mechanisms for Dispute Settlement and Conflict Management within ASEAN. U.C. Davis Journal of International Law \& Policy, 20 (1), 47-73.

Poole, A. (2017) ASEAN and Indonesia Under Jokowi. Retrieved from http://www.internationalaffairs.org.au/australianoutlook/asean-indonesia-under-jokowi/

Poole, A. (2015) Is Jokowi Turning His Back on ASEAN? Retrieved from https://thediplomat.com/2015/09/is-jokowi-turning-his-back-on-asean/

Rattanasevee, P. (2014) Leadership in ASEAN: The Role of Indonesia Reconsidered. Asian Journal of Political Science, 22 (2), 113-127.

Roberts, C.B., \& Widyaningsih, I. (2015) Indonesian Leadership in ASEAN: Mediation, Agency and Extra-Regional Diplomacy. In C.B. Roberts, A.D. Habir \& L.C. Sebastian (Eds.), Indonesia's Ascent: Power, Leadership, and Regional Order (pp. 264-286). London: Palgrave MacMillan.

Salim, T. (2016) Indonesia stresses ASEAN unity. Retrieved from http://www.thejakartapost.com/seasia/2016/09/07/ri-stresses-asean-unity.html

Tamotsu, F. (2015) Japan's New ASEAN Diplomacy?: Why the Abe Doctrine May Be Counterproductive. Retrieved from: https://toyoeiwa.repo.nii.ac.jp/index.php?action=pages_view_main\&active_action=repository _action_common_download\&item_id=508\&item_no=1\&attribute_id $=22 \&$ file_no $=1 \&$ page_i $\mathrm{d}=13 \&$ block_id $=17$

Tavares, J.A.M., Fitriani, E., Ibrahim, A. \& Abdulrahim, R. (2018, January) Talking ASEAN on "ASEAN Outlook 2018." Talking ASEAN Dialogue presented at the Habibie Center, Jakarta.

Weatherbee, D. (2013) Indonesia in ASEAN: Vision and Reality. Singapore: Institute of Southeast Asian Studies. 
Assessing Indonesia's Leadership in the Advancement of ASEAN Political-Security Community under

President Joko Widodo

(2009) International Relations in Southeast Asia: The Struggle for Autonomy. $2^{\text {nd }}$ ed. Rowman \& Littlefield Publishers, Inc.

Wong, C. (2017) After Summit, ASEAN Remains Divided on South China Sea. Retrieved from https://thediplomat.com/2017/05/after-summit-asean-remains-divided-on-south-chinasea/

Yuzawa, T. (2013) ASEAN-Japan Cooperation on Democracy and Human Rights Promotion: Challenges and Opportunities. In R. Sukma \& Y. Soeya (Eds.) Beyond 2015: ASEAN-Japan Strategic Partnership for Democracy, Peace, and Prosperity in Southeast Asia (pp. 241-254). Tokyo: Japan Center for International Exchange. 